\title{
Biomed 101
}

National Cancer Institute

\section{Source}

National Cancer Institute. Biomed 101. NCI Thesaurus. Code C2206.

An agent binding to the leukotriene B4 receptor, leading to reduced interleukin-2

mediated hypoxia. Biomed 101 does not affect interleukin-2 antitumor activity. (NCI04) 